\title{
Study of anti-inflammatory activity of Ficus racemosa linn stem bark extract in albino rats
}

\author{
Priya Mohan B. N. ${ }^{1 *}$, Suma Jayaram², Sanitha Kuriachan ${ }^{1}$
}

${ }^{1}$ Department of Pharmacology, Al Azhar Medical College and Super Speciality Hospital, Thodupuzha, Kerala, India

${ }^{2}$ Department of Pharmacology, St. John's Medical College and Super Speciality Hospital, Bangalore, Karnataka, India

Received: 02 February 2021

Accepted: 18 February 2021

\section{*Correspondence:}

Dr. Priya Mohan B. N.,

Email: priyamohan.n@gmail.com

Copyright: (c) the author(s), publisher and licensee Medip Academy. This is an open-access article distributed under the terms of the Creative Commons Attribution Non-Commercial License, which permits unrestricted non-commercial use, distribution, and reproduction in any medium, provided the original work is properly cited.

\begin{abstract}
Background: Inflammation is part of the complex biological response of vascular tissues to harmful stimuli. Though there are standard anti-inflammatory drugs like aspirin, diclofenac, etc., these are not free of side effects. This has led to an increase in demand for natural products with anti-inflammatory activity having less side effects. Hence the study was conducted to evaluate the anti-inflammatory activity of ethanolic extract of Ficus racemose (EEFR) in albino rats. Methods: Healthy albino rats of either sex were divided into 4 groups of 6 animals each. Group1-control, group 2diclofenac sodium $2 \mathrm{mg} / \mathrm{kg}$ and group 3 and 4 EEFR (200 and $400 \mathrm{mg} / \mathrm{kg}$ respectively), anti-inflammatory activity was evaluated by Carrageenan induced paw oedema: formalin induced-peritonitis and cotton pellet induced granuloma model for in vivo activity and protein denaturation test for in vitro activity.

Results: EEFR exhibited significant in vitro ( $\mathrm{p}<0.001$ ) anti-inflammatory effect at the dose of $200 \mathrm{and} 400 \mathrm{mg} / \mathrm{kg}$. EEFR produced $61.37 \%$ inhibition at the dose of $400 \mathrm{mg} / \mathrm{kg}$ and diclofenac (standard drug) produced $62.95 \%$ of inhibition after 3 hours of drug treatment in carrageenan induced paw oedema. The exudate volume was decreased in formalin induced peritonitis by EEFR and diclofenac significantly ( $\mathrm{p}<0.001)$. In cotton pellet induced granuloma EEFR $(400 \mathrm{mg} / \mathrm{kg})$ and diclofenac showed decreased formation of granuloma by $28.36 \%$ and $28.00 \%$ (p<0.001) respectively. Conclusions: EEFR has significant anti-inflammatory activity in both acute and chronic model in a dose dependant manner in comparison with standard drug.
\end{abstract}

Keywords: Anti-Inflammatory agents, Carrageenan, Diclofenac, Edema, Ficus, Granuloma, Peritonitis

\section{INTRODUCTION}

Inflammation is a protective attempt by the organism to remove the injurious stimuli and to initiate the healing process. However, inflammation is a stereotyped response, and therefore it is considered as a mechanism of innate immunity, as compared to adaptive immunity, which is specific for each pathogen. ${ }^{1}$ Although it is a defence mechanism, the complex events and mediators involved in the inflammatory reaction can induce, maintain or aggravate many diseases. ${ }^{2}$ Inflammatory diseases such as rheumatoid arthritis, inflammatory bowel disease, multiple sclerosis and other connective tissue diseases are a major cause of morbidity. Though there are standard drugs like Aspirin, indomethacin, phenylbutazone, etc. these drugs are not entirely free of side effects and have their own limitation. ${ }^{3}$

This has led to an increase in demand for natural products with anti-inflammatory activity having less side effects. Traditional and folk remedies have provided us with important drugs in the treatment of many diseases and are being increasingly subjected to scientific study. The family of anti-inflammatory drugs is no exception, to this. Salicylates had their origin in the 'willow bark' of folk medicine, paracetamol, cortisone, gold salts, and 
phenylbutazone made their way into clinical medicine serendipitously. ${ }^{3}$

Ficus racemosa commonly known as figs in English, Udumbar in Sanskrit, Gular in Hindi and Atti in Kannada is a widely cultivated plant all over India.

The stem bark is used to treat menorrhagia, leucorrhoea, gonorrhoea, urinary diseases, haemorrhage and skin diseases. ${ }^{4}$ Ethanol extract of stem bark inhibited COX-1 with IC50 value of $100 \mathrm{ng} / \mathrm{ml}$ proves that the drug is used in the treatment of inflammatory conditions. ${ }^{5}$

The bark is highly efficacious in threatened abortion and also recommended in urological disorders, diabetes, hiccough, leprosy, dysentery and piles. ${ }^{6}$ The literature survey reveals inadequate study on the anti-inflammatory activity of bark extract of Ficus racemosa. This prompted to investigate the anti-inflammatory activity of bark extract of Ficus racemosa in acute and chronic experimental models in albino rats.

\section{METHODS}

\section{Animals}

Laboratory bred albino rats of either sex, weighing 150$200 \mathrm{~g}$ were used for the study. The animals were maintained under standard laboratory conditions at $25^{\circ} \mathrm{C}$, commercial pellet diet with water ad libitum and normal photo period (12-hours dark/12-hours light). Experimental protocol has been approved by the institutional animal ethics committee.

\section{Drugs and chemicals}

Diclofenac, carrageenan, formalin, ethanolic extract of Ficus Racemosa stem bark, ether, alcohol, gum acacia, distilled water.

\section{Equipment}

Digital Plethysmograph, oral gavage, syringes (5 and 2 $\mathrm{ml})$, tuberculin syringe, dissection set, animal stand, bell jar, mortar and pestle, gloves and mask.

\section{Extraction procedure of Ficus racemosa}

\section{Plant material}

The dried stem bark of Ficus racemosa was procured from authentic suppliers from Bangalore, Karnataka and was identified by Mrs. Chandrika L., botanist, department of botany, PES university, Bangalore.

\section{Procedure for extraction}

About $1 \mathrm{~kg}$ shade dried stem bark powder of Ficus racemosa was subjected to extraction first with ethanol
$(95 \%)$ in a Soxhlet apparatus (55C; $25-35$ cycles) and then the dried bark was macerated with water for 3 days with distilled water containing chloroform $(2.5 \mathrm{ml} / 1000 \mathrm{ml})$ to remove any impurities and the residue was concentrated by filtration to obtain the ethanolic extract of Ficus racemosa (EEFR). The yield of the extract was $9.5 \% .^{7}$

\section{Establishment of dose of the extract}

Based on the results obtained from earlier study by Prasanna Krishna V. where acute toxicity tests done in rats using OECD 423 guidelines have proven the LD50 of EEFR to be more than $2000 \mathrm{mg} / \mathrm{kg} \mathrm{B}$. W., accordingly the dose of ethanolic extract of Ficus racemosa stem bark for anti-inflammatory activity was fixed to be $200 \mathrm{mg} / \mathrm{kg}$ and $400 \mathrm{mg} / \mathrm{kg}$ body weight. ${ }^{8}$

\section{Inclusion criteria}

Healthy male and female albino rats of 90-120 days old having weight ranges 150-200 gm were included in the study.

\section{Exclusion criteria}

Pregnant and diseased animals are excluded from the study.

\section{In vitro anti-inflammatory activity}

Protein denaturation was performed as described (Elias et al) with slight modifications. Test solution consisting of 1 $\mathrm{ml}$ of different concentrations of Ficus racemosa extract ranging from 200 and $400 \mathrm{mg} / \mathrm{ml}$ and standard diclofenac sodium 1 and $2 \mathrm{mg} / \mathrm{ml}$ was mixed with $1 \mathrm{ml}$ of egg albumin solution $(1 \mathrm{mM})$ and incubated at $27 \pm 1^{\circ} \mathrm{C}$ for 15 minutes. Denaturation was induced by keeping the reaction mixture at $70^{\circ} \mathrm{C}$ in a water bath for 10 minutes. After cooling the turbidity was measured spectrophotometrically at $660 \mathrm{~nm}$. Percentage inhibition of denaturation was calculated from control where no drug was added. Each test was done in triplicate. ${ }^{9}$

\section{Percent inhibition $=100 \times[\mathrm{Vt} / \mathrm{Vc}-1]$}

Where, $\mathrm{Vt}=\mathrm{absorbance}$ of test sample, $\mathrm{Vc}=\mathrm{absorbance}$ of control.

\section{Statistical analysis}

Data is represented as mean $\pm \mathrm{SD}$, which is statistically analysed by ANOVA test and $p<0.001$ considered to be significant.

\section{In vivo anti-inflammatory activity}

It is of Ficus racemosa was assessed by using adult albino rats of either sex weighing about 150-250 gm. The animals were maintained on standard pellet diet and water ad libitum. Overnight fasted albino rats were divided into four 
groups of 6 animals each and were treated as follows. Group 1: Control, receive vehicle (gum acacia), group 2: Standard drug diclofenac sodium $0.2 \mathrm{mg} / 100 \mathrm{gm} \mathrm{B}$. W, group 3: Test 1 EEFR low dose, $20 \mathrm{mg} / 100 \mathrm{gm} \mathrm{B}$. W and group 4: Test 2 EEFR high dose, $40 \mathrm{mg} / 100 \mathrm{gm} \mathrm{B}$. W.

\section{Models used}

\section{Acute inflammation}

Carrageenan induced paw oedema in rats and formalin induced peritonitis in rats.

\section{Chronic inflammation}

Cotton pellet induced granuloma in rats.

\section{Carrageenan induced paw oedema in rats ${ }^{10}$}

Inflammation was produced by sub plantar injection of 0.1 $\mathrm{ml}$ of freshly prepared $1 \%$ carrageenan in normal saline in right hind paw of the rat. Paw volume was measured by digital Plethysmometer at 0 and 3 hours after carrageenan injection. Animals were premedicated either with vehicle, Ficus extract or diclofenac orally one hour before carrageenan injection. Mean increase in paw volume was measured and percentage inhibition in standard and test group was calculated by using the below mentioned formula.

\section{Percent oedema inhibition $=(\mathrm{Vc}-\mathrm{Vt}) / \mathrm{Vcx} 100$}

Where, Vc-Mean oedema volume in the control group, VtMean oedema volume in the test group.

\section{Formalin induced-peritonitis in rats ${ }^{11}$}

The method of Teotino et al was adopted here to study the acute inflammatory reaction induced by formalin injected into the peritoneal cavity of the rats. All the rats were fed orally with the respective drug and one hour later peritonitis was induced by intra peritoneal administration of $1 \mathrm{ml}$ of $1 \%$ formalin. After 4 hours the rats were sacrificed and the abdominal cavity was opened. The exudates were collected and measured by placing the animal on a glass funnel.

The anti-inflammatory activity of the drugs was calculated by the following formula,

Percent anti-exudate activity $=100(1-\mathrm{Vt} / \mathrm{Vc})$

Where, $\mathrm{Vc}=$ mean volume of exudates in the control group, $\mathrm{Vt}=$ mean volume of exudates in the test group.

After four hours peritoneal fluid which was collected and measured was subjected to peritoneal fluid analysis, which was processed by centrifugation at $2000 \mathrm{rpm}$ for $10 \mathrm{~min}$ and RBCs were destroyed. The total leukocyte count was determined using Neubauer chamber.

\section{Cotton pellet induced granuloma in rats ${ }^{10}$}

The method of Winter and Porter with slight modification was used to study chronic inflammation. 55 Four groups of six animals in each group were taken, anaesthetized with ether. The axillary skin was shaved and disinfected with $70 \%$ ethanol. An incision was made and by a blunt forceps subcutaneous tunnels were formed and a sterilized cotton pellet of $20 \mathrm{mg}$ was placed in both axillae. The vehicle, test drug and standard drug were administered for 7 consecutive days starting from day of cotton implantation. At $8^{\text {th }}$ day rats were anaesthetized again and the cotton pellet (along with granular tissue formed around) were removed surgically and freed from extraneous tissue. The pellets were dried in an incubator at $60^{\circ} \mathrm{C}$ until a constant weight was obtained. Mean increase in the weight of cotton pellet was considered as weight of granulation tissue.

Percentage inhibition of granulation formation in standard group and test group was calculated by:

Percentage inhibition $=[\mathrm{Wc}-\mathrm{Wd} / \mathrm{Wc}] \times 100$

Wc=Difference in pellet weight of the control group, $\mathrm{Wd}=$ Difference in pellet weight of the drug treated group.

\section{Statistical analysis}

Statistical analysis of data was done using one-way analysis of variance (ANOVA) followed by post-Hoc Tukey test using the software namely SAS 9.2, SPSS 15.0, Stata 10.1, MedCalc 9.0.1, Systat 12.0 and R environment ver 2.11.1 and Microsoft word and excel have been used to generate graphs, tables etc. $\mathrm{P}$ value $<0.05$ was considered statistically significant.

\section{RESULTS}

Table 1 shows invitro anti-inflammatory activity of Ficus racemosa stem bark with reference to diclofenac sodium using protein denaturation test, EEFR (20 and $40 \mathrm{mg} / 100$ gm B. W.) showed significant inhibition of denaturation of egg albumin in a concentration dependent manner.

The EEFR at concentration of $40 \mathrm{mg} / 100 \mathrm{gm} \mathrm{B}$. W and diclofenac at concentration of $2 \mathrm{mg} / \mathrm{ml}$ showed maximum inhibition of protein denaturation of 71.32 and $73.52 \%$ respectively when compared with control, proving the anti-inflammatory activity of EEFR.

In Carrageenan induced rat paw oedema (Figure 1) inhibition method, Table 2 the extract produced dose dependent inhibition of oedema. At a dose of 20 and 40 $\mathrm{mg} / 100 \mathrm{gm} \mathrm{B}$. W. the extract showed 54.49 and $61.37 \%$ inhibition of paw oedema respectively $(\mathrm{p}<0.001)$ in comparison with the control group. The standard group 
treated with diclofenac inhibited oedema by $62.95 \%$ $(\mathrm{p}<0.001)$.

Table 1: Protein denaturation test.

\begin{tabular}{|c|c|c|}
\hline Group & $\begin{array}{l}\text { Absorbance } \\
\text { at } 660 \mathrm{~nm}\end{array}$ & $\begin{array}{l}\text { Inhibition of } \\
\text { denaturation }(\%)\end{array}$ \\
\hline Control & $1.36 \pm 0.006$ & - \\
\hline $\begin{array}{l}\text { Diclofenac } 1 \\
\text { mg/ml }\end{array}$ & $0.72 \pm 0.007 * *$ & 47.05 \\
\hline $\begin{array}{l}\text { Diclofenac } 2 \\
\mathrm{mg} / \mathrm{ml}\end{array}$ & $0.36 \pm 0.007 * *$ & 73.52 \\
\hline $\begin{array}{l}\text { EEFR } 20 \\
\text { mg/100 gm B. } \\
\text { W. }\end{array}$ & $1.04 \pm 0.17 * *$ & 23.52 \\
\hline $\begin{array}{l}\text { EEFR } 40 \\
\mathrm{mg} / 100 \mathrm{gm} \\
\text { B. W. }\end{array}$ & $0.39 \pm 0.005^{* *}$ & 71.32 \\
\hline
\end{tabular}

All values are expressed as mean $\pm \mathrm{SD}, \mathrm{n}=3, * * \mathrm{p}<0.001$. SD: standard deviation.

Table 2: Effect of EEFR on carrageenan induced rat paw oedema.

\begin{tabular}{|llll|}
\hline Group & $\begin{array}{l}\text { Baseline } \\
\text { paw vol } \\
(\mathbf{m l})\end{array}$ & $\begin{array}{l}\text { Increase in } \\
\text { paw volume } \\
(\mathbf{m l}) \text { after } 3 \\
\text { hours }\end{array}$ & $\begin{array}{l}\text { Edema } \\
\text { inhibition } \\
(\%)\end{array}$ \\
\hline Control & $0.93 \pm 0.05$ & $1.56 \pm 0.06$ & - \\
\hline $\begin{array}{l}\text { Diclofenac } \\
\text { (0.2 mg/100 } \\
\text { gm B.W.) }\end{array}$ & $1.03 \pm 0.07$ & $1.26 \pm 0.07 * *$ & $62.95 \pm 2.7$ \\
\hline $\begin{array}{l}\text { EEFR- (20 } \\
\text { mg/100 gm } \\
\text { B. W. })\end{array}$ & $1.05 \pm 0.05$ & $1.34 \pm 0.06 * *$ & $54.49 \pm 6.5$ \\
\hline $\begin{array}{l}\text { EEFR- (40 } \\
\text { mg/100 gm }\end{array}$ & $1.04 \pm 0.05$ & $1.29 \pm 0.06 * *$ & $61.37 \pm 1.6$ \\
\hline B.W.) & & & \\
\hline
\end{tabular}

All values are expressed as mean $\pm \mathrm{SD}, \mathrm{n}=6$, $* * \mathrm{p}<0.001$. SD: standard deviation.

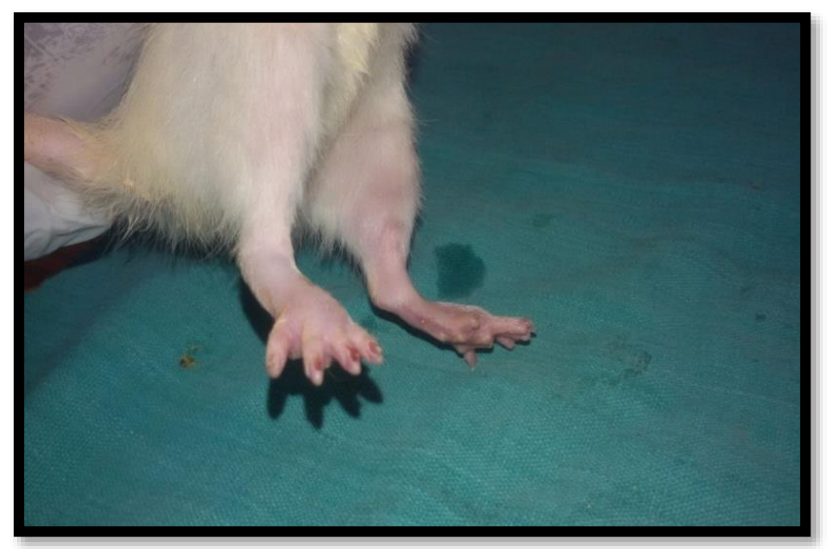

Figure 1: Carrageenan induced paw oedema in rat.

Table 3 showing percentage inhibition of exudate volume in EEFR was maximum $51.71 \%(\mathrm{p}<0.001)$ with high dose
(40 mg/100 gm B. W.) where as in standard group it was $63.33 \%(\mathrm{p}<0.001)$.

Table 4, total leukocyte count in formalin induced peritonitis model shows that EEFR is effective in reducing peritonitis induced by formalin (Figure 2).

Table 5 showing cotton pellet induced granuloma in rats (Figure 3), EEFR significantly decreased the dry weight of the granuloma when compared to the control group. The percentage inhibition of extract was highest at the dose of $40 \mathrm{mg} / 100 \mathrm{gm}$ B. W. $28 \% \quad(\mathrm{p}<0.001)$ which was comparable to that of diclofenac $28.36 \%$ ( $\mathrm{p}<0.001)$.

Table 3: Peritoneal exudate volume in formalin induced peritonitis model.

\begin{tabular}{|lll|} 
Group & $\begin{array}{l}\text { Peritoneal } \\
\text { exudate vol }(\mathrm{ml})\end{array}$ & $\begin{array}{l}\text { Inhibition } \\
(\%)\end{array}$ \\
\hline Control & $3.22 \pm 0.29$ & - \\
\hline $\begin{array}{l}\text { Diclofenac (0.2 } \\
\text { mg/100 gm B.W.) }\end{array}$ & $1.18 \pm 0.26^{* *}$ & $63.33 \pm 8.25$ \\
\hline $\begin{array}{l}\text { Test 1-EEFR (20 } \\
\text { mg/100 gm B. W.) }\end{array}$ & $2.27 \pm 0.25^{* *}$ & $29.38 \pm 7.80$ \\
\hline $\begin{array}{l}\text { Test 2-EEFR (40 } \\
\text { mg/100 gm B. W.) }\end{array}$ & $1.55 \pm 0.15^{* *}$ & $51.71 \pm 4.71$ \\
\hline
\end{tabular}

All values are expressed as Mean $\pm \mathrm{SD}, \mathrm{n}=6, * * \mathrm{p}<0.001$. SD: standard deviation.

Table 4: Total leukocyte count in formalin induced peritonitis model.

\begin{tabular}{|lll|}
\hline Group & $\begin{array}{l}\text { Total leukocyte } \\
\text { count } \\
\text { (cells/cu.mm) }\end{array}$ & $\begin{array}{l}\text { Inhibition } \\
(\%)\end{array}$ \\
\hline Control & $4833.33 \pm 480.28$ & - \\
\hline $\begin{array}{l}\text { Diclofenac (0.2 } \\
\text { mg/100 gm B.W.) }\end{array}$ & $1316.67 \pm 163.30^{* *}$ & $72.75 \pm 3.38$ \\
\hline $\begin{array}{l}\text { Test 1-EEFR (20 } \\
\text { mg/100 gm B. W.) }\end{array}$ & $1850.00 \pm 178.89 * *$ & $61.72 \pm 3.70$ \\
\hline $\begin{array}{l}\text { Test 2-EEFR (40 } \\
\text { mg/100 gm B. W.) }\end{array}$ & $1375.00 \pm 175.36 * *$ & $71.55 \pm 3.63$ \\
\hline
\end{tabular}

All values are expressed as mean $\pm \mathrm{SD}, \mathrm{n}=6, * * \mathrm{p}<0.001$. SD: standard deviation.

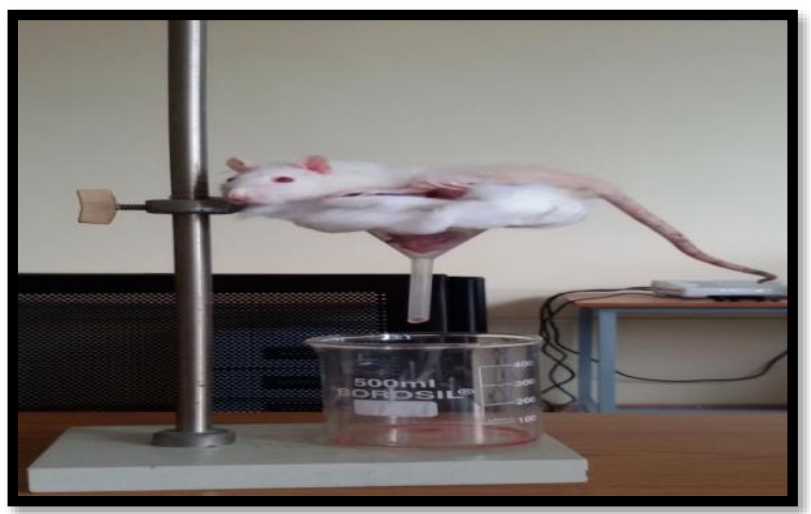

Figure 2: Formalin induced-peritonitis in rat. 
Table 5: Cotton pellet-induced granuloma in rats.

\begin{tabular}{|c|c|c|c|}
\hline Group & $\begin{array}{l}\text { Initial weight of } \\
\text { cotton pellet (mg) }\end{array}$ & $\begin{array}{l}\text { Weight of cotton pellet after } \\
7 \text { days ( } \mathrm{mg} \text { ) }\end{array}$ & Inhibition (\%) \\
\hline Control & $40.00 \pm 0.0$ & $88.96 \pm 7.61$ & - \\
\hline Diclofenac (0.2 mg/100 gm B.W.) & $40.00 \pm 0.0$ & $63.73 \pm 4.20 * *$ & $28.36 \pm 4.72$ \\
\hline Test 1-EEFR (20 mg/100 gm B. W.) & $40.00 \pm 0.0$ & $82.47 \pm 4.37$ & $7.29 \pm 4.91$ \\
\hline Test 2-EEFR (40 mg/100 gm B. W.) & $40.00 \pm 0.0$ & $64.05 \pm 1.33 * *$ & $28.00 \pm 1.48$ \\
\hline
\end{tabular}

All values are expressed as mean $\pm \mathrm{SD}, \mathrm{n}=6, * * \mathrm{p}<0.001$. SD: standard deviation.

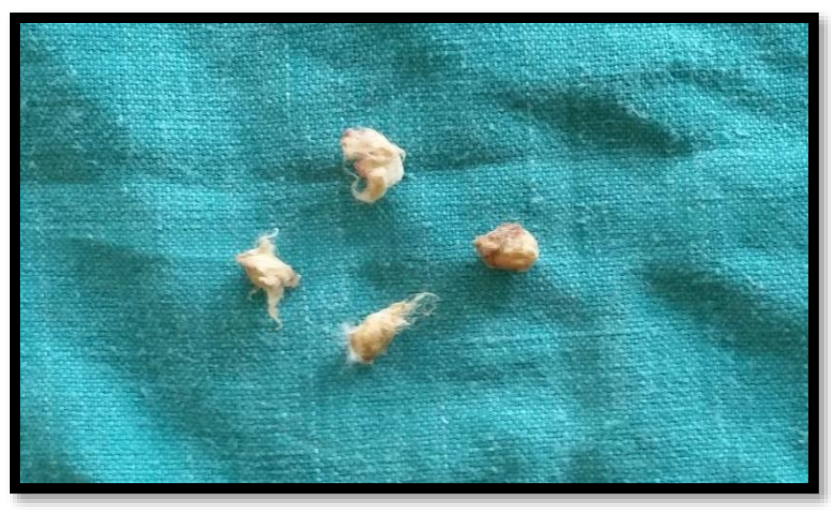

Figure 3: Cotton pellet granuloma.

\section{DISCUSSION}

Inflammation is a reaction of the body against an aggressive agent, characterized by vasodilatation and access of fluid and cells to the target tissue. ${ }^{12}$ Inflammatory mediators such as cytokines, histamine, serotonin, leukotrienes and prostaglandins, increase the vascular permeability and migration of leukocytes to inflamed tissue. ${ }^{13}$ In addition, different pathologic processes, such as cardiovascular and metabolic disorders, peptic ulcer and cancer are related to inflammation. ${ }^{14-18}$ Although nonsteroidal anti-inflammatory drugs are widely employed for controlling inflammatory disorders, adverse effects (e.g., gastric perforations, stomach ulcers and cardiovascular complications) are commonly observed, leading to increasing interest in research on the development of alternative tools that exhibit novel mechanisms of action from different origins. ${ }^{19-21}$

Hence, present study was done to screen acute and chronic anti-inflammatory activity of ethanolic extract of Ficus racemosa stem bark in both in vitro and in vivo models. There are studies showing anti-inflammatory activity of Ficus racemosa leaves, but not on stem bark. ${ }^{22-24}$

In this study anti-inflammatory activity of Ficus racemosa stem bark was studied with reference to diclofenac sodium using in vitro and in vivo anti-inflammatory models.

In protein denaturation test EEFR (200 and $400 \mathrm{mg} / \mathrm{ml}$ ) showed significant inhibition of denaturation of egg albumin in a concentration dependent manner.
The EEFR at concentration of $400 \mathrm{mg} / \mathrm{ml}$ and diclofenac at concentration of $2 \mathrm{mg} / \mathrm{ml}$ showed maximum inhibition of protein denaturation of 71.32 and $73.52 \%$ respectively when compared with control, proving the antiinflammatory activity of EEFR.

Denaturation of tissue proteins is one of the welldocumented causes of inflammatory and arthritic diseases. Production of auto antigens in certain arthritic diseases may be due to denaturation of proteins in vivo. ${ }^{25,26}$ Agents that can prevent protein denaturation therefore, can be used for anti-inflammatory drug development.

In Carrageenan induced rat paw oedema inhibition Method, the extract produced dose dependent inhibition of

oedema. At a dose of 200 and $400 \mathrm{mg} / \mathrm{kg}$ the extract showed 54.49 and $61.37 \%$ inhibition of paw oedema respectively $(\mathrm{p}<0.001)$ in comparison with the control group. The standard group treated with diclofenac inhibited oedema by $62.95 \%(\mathrm{p}<0.001)$.

In a previous study by Sunil ethanol extract of Ficus racemosa stem bark at the maximum dose $(500 \mathrm{mg} / \mathrm{kg})$ showed comparatively significant $(\mathrm{p}<0.01)$ inhibition of paw volume in carrageenan and egg albumin induced paw oedema method to that of standard diclofenac sodium (100 $\mathrm{mg} / \mathrm{kg}) .{ }^{27} \mathrm{In}$ another study by Mehtaa aqueous extract of Ficus racemosa stem bark at a dose of $20 \mathrm{mg}$ and 40 $\mathrm{mg} / 100 \mathrm{gm}$ showed significant anti-inflammatory activity. ${ }^{28}$

The development of carrageenan-induced edema has two phases; the early phase is attributed to the release of histamine, serotonin and kinins and the late phase is related to the release of prostaglandins and bradykinins. ${ }^{29-32} \mathrm{TNF}$ $\alpha$ is also a mediator of carrageenan-induced inflammation and is able to enhance the further release of kinins and leukotrienes. ${ }^{33}$

On the basis of the time of action of ethanolic extract of Ficus racemosa stem bark it is inferred that the inhibitory effect of carrageenan induced inflammation could be due to inhibition of the enzyme cyclo-oxygenase leading to inhibition of prostaglandin synthesis, similar to standard anti-inflammatory drug diclofenac. 
Formalin when injected into peritoneal cavity irritates the peritoneum and bowel and induces acute inflammatory reaction producing aseptic peritonitis. According to a previous study, formalin at a low dose of $1.75 \%$ induces an oedema which mainly results from a neurogenic inflammation mediated by neuropeptides such as substance P. At higher dose of 5\%, formalin induces oedema which mainly depends on the release of substance $\mathrm{P}$, prostanoids, 5-hydroxytryptamine and histamine. ${ }^{34}$

In our study percentage inhibition of exudate volume in EEFR was maximum $51.71 \%(\mathrm{p}<0.001)$ with high dose $(400 \mathrm{mg} / \mathrm{kg})$ where as in standard group it was $63.33 \%$ ( $p<0.001)$. The above results show that EEFR is effective in reducing peritonitis induced by formalin. There are no studies documented till date on this activity of EEFR.

The cotton pellet granuloma model has been widely employed to assess the transudative, exudative and proliferative components of chronic inflammation. There are three phases in the inflammatory response in the cotton pellet induced granuloma. ${ }^{35}$ In the first phase imbibition of fluid containing low protein takes place at the site of cotton pellet implantation. In the second phase after 2-3 days of pellet implantation, exudation of fluid containing the protein takes place. In the 3rd phase, i.e., the proliferative phase, appearance of collagen, mucopolysaccharide synthesis, and increase in the number of fibroblasts around the cotton pellets occurs. ${ }^{36}$

The fluid absorbed by the pellet greatly influences the wet weight of the granuloma and the dry weight correlates well with the amount of granulomatous tissue formed. ${ }^{37}$

The increase in dry weight of the granuloma measures the proliferative phase due to monocyte infiltration and fibroblast proliferation that take place in chronic inflammation.

In this study, ethanolic extract of Ficus racemosa significantly decreased the dry weight of the granuloma when compared to the control group. The percentage inhibition of extract was highest at the dose of $400 \mathrm{mg} / \mathrm{kg}$, $28 \% \quad(\mathrm{p}<0.001)$ which was comparable to that of diclofenac $28.36 \%(\mathrm{p}<0.001)$.

This anti-inflammatory action may be due to the ability of EEFR in reducing the number of fibroblasts and inhibiting the synthesis of collagen and mucopolysaccharide, which are natural proliferative agents of granulation tissue formation.

The above results show that ethanolic extract of Ficus racemosa stem bark possesses significant $(\mathrm{p}<0.001)$ antiinflammatory activity in both acute and chronic inflammatory models. Further studies are required to confirm the active compounds responsible for antiinflammatory activity.

\section{CONCLUSION}

The study shows that ethanolic extract of Ficus racemosa stem bark has significant anti-inflammatory activity and is comparable with standard anti-inflammatory drug diclofenac. Thus, ethanolic extract of Ficus racemosa stem bark shows a promise in the development of new antiinflammatory drugs and further studies can be considered on isolation and fractionation of active components to determine the exact constituents that are responsible for these activities.

\section{Funding: No funding sources}

Conflict of interest: None declared

Ethical approval: The study was approved by the Institutional Ethics Committee

\section{REFERENCES}

1. Abbas AB, Lichtman AH. In Innate Immunity, ch. 2 . In Saunders (Elsevier). Basic Immunology. Functions and disorders of the immune system. 2009;3.

2. Sosa S, Balicet MJ, Arvigo R, Esposito RG, Pizza C, Altinier GA et al. Screening of the topical antiinflammatory activity of some Central American plants. J. Ethnopharmacol. 2002;8:211-5.

3. Jay AN, Jagir P, Semuel MR, Shabaraya AR. Antiinflammatory activity of fractionated extracts of Achyranthes aspera Linn leaves. J Appl Pharmace Sci. 2011;1(8):188-90.

4. Patil VV, Pimprikar RB, Sutar NG. AntiHyperglycemic activity of leaves. J Pharm Res 2009;2:54-57.

5. Deep P, Singh AK, Md. Ansari T, Raghav P. Pharmacological Potentials of Ficus racemosa-A Review. Int J Pharm Sci Rev Res. 2013;22(1):29-34.

6. Rageeb M, Usman M, Rohit P. Medicinal uses of Ficus racemosa linn. Int J Pharmac Arch. 2013;2(3):33-42.

7. Gowda SKP, Swamy VBM. Protective effect of stem bark ethanol and aqueous extracts of Ficus racemosa against cisplatin induced nephrotoxicity in mice. Int $\mathbf{J}$ Res Pharm Chem. 2011;1(3);465-9.

8. Prasanna Krishna V, Sunil V, Venugopal Johnson P. Evaluation of Acute and Chronic Toxicity Studies of Ethanolic Extract Of Ficus Glomerata L. Int J Pharmac Develop Technol. 2011;1(2):66-70.

9. Mallikadevi T, Paulsamy S, Karthika K, Jamuna S. In Vitro And In Vivo Anti-Inflammatory Activity Of Whole Plant Methanolic Extract Of Mukia Maderaspatana (L.) M. Roem. (Cucurbitaceae) Int J Pharm Pharm Sci. 2012;4(5):435-9.

10. Gerhard Vogel H. Analgesic, Anti-Inflammatory, and Anti-Pyretic Activity. Drug Discovery and Evaluation: Pharmacological Assays. SpringerVerlag Berlin Heidelberg New York. 2008;3:1047113.

11. Bhuvana KB, Hema NG. An evaluation of aloe vera for its acute anti-inflammatory activity in rat 
peritonitis model. World J Pharmac Res. 2014;3(3):4508-19.

12. Schmid-Schönbein W. Analysis of inflammation. Annu Rev Biomed Eng. 2006;8:93-151.

13. Brenner PS, Krakauer T. Regulation of inflammation: A review of recent advances in anti-inflammatory strategies. Curr Med Chem Anti-Inflamm AntiAllergy Agents. 2003;2:274-83.

14. Hansson GK. Inflammation, atherosclerosis, and coronary artery disease. $\mathrm{N}$ Engl $\mathrm{J}$ Med. 2005;352:1685-95.

15. Hotamisligil GS. Inflammation and metabolic disorders. Nature. 2006;444:860-7.

16. Tarzami ST. Chemokines and inflammation in heart disease: Adaptive or maladaptive? Int J Clin Exp Med. 2011;4:74-80.

17. Watanabe $\mathrm{T}$, Higuchi $\mathrm{K}$, Tanigawa $\mathrm{T}$, Tominaga $\mathrm{K}$, Fujiwara Y, Arakawa T. Mechanisms of peptic ulcer recurrence: role of inflammation. Inflammo pharmacol. 2002;10:291-302.

18. Smith GR, Missailidis S. Cancer, inflammation and the AT1 and AT2 receptors. J. Inflamm. 2004;1:1-12.

19. Fosslien E. Review: Cardiovascular complications of non-steroidal anti-inflammatory drugs. Ann Clin Lab Sci. 2005;35:347-85.

20. Pereira LP, Da Silva RO, Ringel PHSF, Da Silva KES, Assreuy AMS, Pereira MG. Polysaccharides fractions of Caesalpinia ferrea pods: Potential antiinflammatory usage. J Ethnopharmacol. 2012;139:642-8.

21. De Brito TV, Prudêncio RS, Sales AB, Júnior FCV, Candeira SJN, Franco AX et al. Anti-inflammatory effect of a sulphated polysaccharide fraction extracted from the red algae Hypnea musciformis via the supression of neutrophil migration by the nitric oxide signalling pathway. J Pharm Pharmacol. 2013; 65:724-33.

22. Mandal SC, Maity TK, Das J, Saha BP, Pal M, Antiinflammatory evaluation of Ficus Racemosa Linn Leaf extract, J Ethnopharmacol. 2000;72(1-2):87-92.

23. Forestieri AM, Monfotre MT, Ragusa S, Trovato A, Lauk L, Anti-inflammatory, analgesic and antipyretic activity in rodents of plant extracts used in Africans Medicine. Phytother Res. 1996;10(2):100-3.

24. Li RW, Leach DN, Myers SP, Lin GD, Leach GJ, Waterman PG. A new anti-inflammatory glucoside from Ficus Racemosa Linn. Planta Med. 2004;70(5):421-6.

25. Opie EL. On the relation of necrosis and inflammation to denaturation of proteins. J Exp Med. 1962;115:597608.

26. Umapathy E, Ndebia EJ, Meeme A, Adam B, Menziwa $\mathrm{P}$, Nkeh-Chungag $\mathrm{BN}$ et al. An experimental evaluation of Albuca setosa aqueous extract on membrane stabilization, protein denaturation and white blood cell migration during acute inflammation. J Med Plants Res. 2010;4:789-95.

27. Sunil LH, Priyanka SH. Evaluation of analgesic and anti-inflammatory activity of Ficus racemosa Linn. stem bark extract in rats and mice. Pharmacogosy J. 2010;2(6)65-70.

28. Mehtaa DS, Katariab BC, Chhaiyaa SB. Wound healing and anti-inflammatory activity of extract of Ficus racemosa linn. bark in albino rats. Int $\mathrm{J}$ Basic Clin Pharmacol. 2012;1(2):111-5.

29. Crunkhorn P, Meacock SC. Mediators of the inflammation induced in the rat paw by carrageenin. Bri J Pharmacol. 1971;42(3):392-402.

30. Vane J, Booting R. Inflammation and mechanism of action of anti-inflammatory drugs. FASEB J. 1987;1:89-96.

31. Nivsarkar M, Mukherjee M, Patel M, Padh H, Bapu C. Launaea nudicaulis leaf juice exhibits antiinflammatory action in acute and chronic inflammation models in rats. Indian Drugs. 2002;39:290.

32. Vinegar R, Schreiber W, Hugo R. Biphasic development of carrageenin edema in rats. $\mathrm{J}$ Pharmacol Exp Ther. 1969;166:96-103.

33. Tonussi CR, Ferreira SH. Tumour necrosis factor$\alpha$ mediates carrageenin-induced knee-joint incapacitation and also triggers overt nociception in previously inflamed rat knee-joints. Pain. 1999;82(1):81-7.

34. Damas J, Liégeois JF. The inflammatory reaction induced by formalin in the rat paw. Naunyn Schmiedebergs Arch Pharmacol. 1999;359(3):220-7.

35. Arrigoni-Martelli E. Inflammation and Antiinflammatories. New York: Spectrum Publication Inc. 1977;119-20.

36. Swingle KF, Shideman FE. Phases of the inflammatory response to subcutaneous implantation of a cotton pellet and their modification by certain anti-inflammatory agents. J Pharmacl Exp Therap. 1972;13:226-34.

37. Babu P, Pandikumar P, Ignacimuthu S. Antiinflammatory activity of Albizia lebbeck Benth., an ethomedicinal plant, in acute and chronic animal models of inflammation. $\mathrm{J}$ Ethnopharmacol. 2009;125:356-60.

Cite this article as: Mohan PBN, Jayaram S,

Kuriachan S. Study of anti-inflammatory activity of Ficus racemosa linn stem bark extract in albino rats. Int J Basic Clin Pharmacol 2021;10:231-7. 